\title{
Functional localisation and scintigraphy in neuroendocrine tumours of the gastrointestinal tract and pancreas (GEP-NETs)
}

\author{
Wouter W de Herder
}

Section of Endocrinology, Department of Internal Medicine, Erasmus MC, 's Gravendijkwal 230, 3015 CE Rotterdam, The Netherlands

Correspondence

should be addressed

to $\mathrm{W}$ W de Herder

Email

w.w.deherder@erasmusmc.nl

\begin{abstract}
For patients with neuroendocrine tumours (NETs) of the gastrointestinal tract and pancreas (GEP) (GEP-NETs), excellent care should ideally be provided by a multidisciplinary team of skilled health care professionals. In these patients, a combination of nuclear medicine imaging and conventional radiological imaging techniques is usually mandatory for primary tumour visualisation, tumour staging and evaluation of treatment. In specific cases, as in patients with occult insulinomas, sampling procedures can provide a clue as to where to localise the insulin-hypersecreting pancreatic NETs. Recent developments in these fields have led to an increase in the detection rate of primary GEP-NETs and their metastatic deposits. Radiopharmaceuticals targeted at specific tumour cell properties and processes can be used to provide sensitive and specific whole-body imaging. Functional imaging also allows for patient selection for receptor-based therapies and prediction of the efficacy of such therapies. Positron emission tomography/computed tomography (CT) and single-photon emission CT/CT are used to map functional images with anatomical localisations. As a result, tumour imaging and tumour follow-up strategies can be optimised for every individual GEP-NET patient. In some cases, functional imaging might give indications with regard to future tumour behaviour and prognosis.
\end{abstract}

\section{Introduction}

Neuroendocrine tumours (NETs) of the gastrointestinal tract and pancreas (GEP) (GEP-NETs) constitute a heterogeneous group of diseases $(1,2,3)$. According to the current WHO grading system, GEP-NETs can be classified according to their Ki-67 proliferation index (MIB-1 staining) into grade 1 (G1), with a Ki-67 index amounting to, or $<2 \%$, G2 with a Ki-67 index between 3 and 20\% and
G3 with a Ki-67 index higher then 20\% (4, 5). Grading correlates well with the clinical course of patients harbouring these GEP-NETs $(6,7,8$, 9). In addition, clinical features such as the primary localisation of these GEP-NETs, the secretion of excessive amounts of hormones or peptides by these GEP-NETs and the metastatic spread, as reflected by staging of these GEP-NETs, also

Invited Author's profile

Wouter W de Herder MD, PhD is Professor of Endocrine Oncology at the Erasmus MC in Rotterdam, The Netherlands. In this University Hospital he is active as the head of education in endocrinology. He is also chairman of a multidisciplinary group for endocrine oncology in the Erasmus MC (tumorwerkgroep endocriene tumoren) and he is head of the ENETS Centre of Excellence for Neuroendocrine Tumors in Rotterdam. He is also a member of several international and Dutch national societies. His major research interests are neuroendocrine and adrenal tumors/Cushing's syndrome.

(c) 2014 European Society of Endocrinology Printed in Great Britain

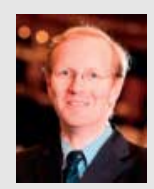

Published by Bioscientifica Ltd 
determine their clinical manifestations and contribute to their prognosis $(1,10,11)$.

Various imaging modalities can be used to localise GEP-NETs (12). Conventional imaging modalities include transabdominal ultrasound (US) and endoscopic US (EUS), computed tomography (CT), magnetic resonance imaging (MRI) and bone scintigraphy. These techniques are used to localise primary GEP-NETs and to determine their metastatic spread. Functional imaging can be used to study physiological and chemical processes and changes in chemical composition, including metabolism, and also (changes in) blood flow and absorption. Molecular imaging can be used for the visualisation and follow-up of processes at the molecular and cellular level in the intact patient without disturbing them $(12,13)$. Sampling procedures aim to localise functional GEP-NETs by measuring appropriate hormonal gradients in the blood, both before and sometimes after the local or systemic i.v. or intra-arterial administration of stimulatory agents.

This review summarises the current status of the different molecular imaging and sampling methods that can be applied for the diagnosis and localisation of the different GEP-NETs.

\section{Somatostatin receptor scintigraphy}

Most GEP-NET cells show a high expression of high-affinity somatostatin receptors (14). Five different somatostatin receptor subtypes (SSTRs, namely SSTR1, SSTR2, SSTR3, SSTR4 and SSTR5) have been cloned and characterised $(14,15)$. The subtype $s_{2} t_{2(a)}$ is expressed in more than $80 \%$ of GEP-NET cells. This receptor subtype is important with regard to its ability to bind the current commercially available somatostatin analogues (SSAs) and the radiolabelled SSAs $(14,16)$. Other ssts are also involved, but their expression is generally lower on GEP-NET cells (14).

Historically, ${ }^{111}$ In-pentetreotide (OctreoScan) is in use for somatostatin receptor scintigraphy (SRS) (13) (Fig. 1). This radiopharmaceutical preferentially binds to sst $_{2(a)}$ and with decreasing lower affinities to also $\mathrm{sst}_{5}$ and $\mathrm{sst}_{3}$ $(2,14,17)$. Planar and single-photon emission CT (SPECT) images are generally obtained 24 and $48 \mathrm{~h}$ after injection of this radiopharmaceutical $(2,18,19)$. For a detailed protocol, the reader is referred to the literature $(18,19)$. The reported overall sensitivity of SRS for well-differentiated (grades 1 and 2) GEP-NETs is also more than $80 \%$. Combining SRS and SPECT-CT allows functional localisation to be correlated with anatomic localisation. SRS plays an important role in the localisation of primary GEP-NETs and their metastases and can also be used for the
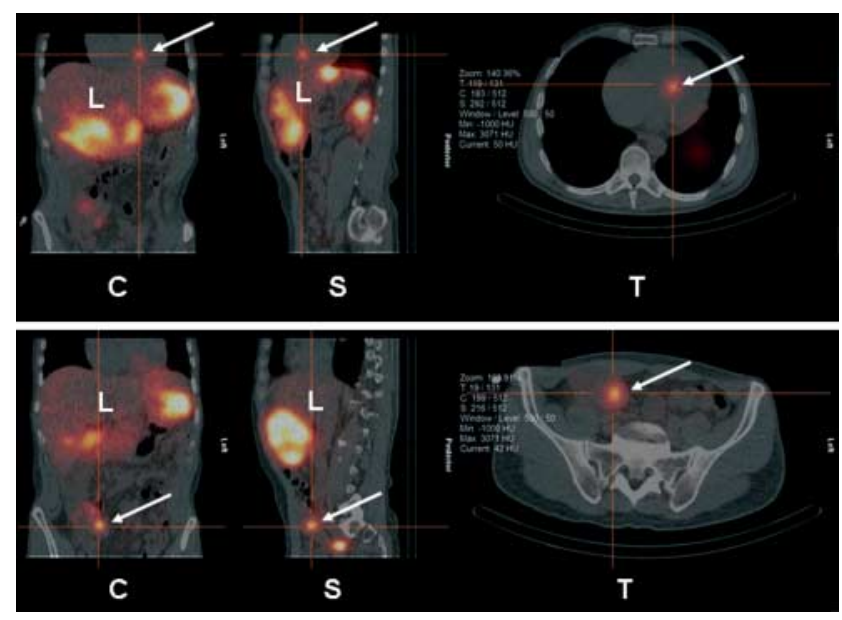

\section{Figure 1}

Coronal (C), sagittal (S) and transverse (T) OctreoScan SPECT/CT images of a 58-year-old man with a metastatic, grade 2, neuroendocrine tumour (carcinoid) of the ileocecal area with liver metastases, an intra-cardiac metastasis and intraabdominal lymph node metastases and the carcinoid syndrome showing a metastasis in the septum of the heart (top panel, arrow), liver (L) metastases and the primary ileocecal tumour (bottom panel, arrow). Courtesy of Dr D J Kwekkeboom.

monitoring of treatment responses in patients with these tumours in combination with conventional - anatomical imaging (CT and MRI). SRS with ${ }^{111}$ In-pentetreotide has been used to predict the clinical efficacy of current commercially available SSAs and for the selection of patients for peptide receptor radionuclide therapy (PRRT) using $\beta$-radiation-emitting SSAs $(20,21,22,23)$.

Physiological uptake of radiolabelled SSAs occurs in pituitary, thyroid, kidneys, liver and spleen (18). Falsepositive SRS in GEP-NETs might occur in patients with accessory spleen(s), infections, adrenal medullary tumours and sometimes in the uncinate process of the pancreas (13).

The sensitivity of SRS is generally lower in:

- Small tumours with a diameter generally $<1 \mathrm{~cm}$, due to insufficient tumour-to-background uptake ratios of radioactivity (13);

- non-metastasised insulinomas (sensitivity $<50 \%$ ), reflecting the generally low $\operatorname{sst}_{2(a)}$ expression in this specific group of benign pancreatic NETs $(13,24)$; and

- NETs or neuroendocrine carcinomas (NECs) with a high Ki-67 index, reflecting dedifferentiation and loss of ssts; in these cases, ${ }^{18}$ F-fluorodeoxy-D-glucose $\left({ }^{18} \mathrm{~F}-\mathrm{FDG}\right)$ positron emission tomography (PET) might be a better option for total body imaging (see below) (25). 
Other radiolabelled SSAs with varying affinities for the different ssts are either still under investigation or already being used in a few centres. When compared with ${ }^{111}$ In-pentetreotide, ${ }^{99 \mathrm{~m}}$ Tc-labelled SSAs are cheaper and include ${ }^{99 \mathrm{~m}} \mathrm{Tc}$-depreotide, which preferentially binds with high affinity to $\mathrm{sst}_{2(\mathrm{a})}, \mathrm{sst}_{3}$ and $\mathrm{sst}_{5}$ (26), and ${ }^{99 \mathrm{~m}}$ Tc-vapreotide, which preferentially binds with high affinity to $s s t_{2(a)}$ and $s t_{5}$ and with lower affinity to $s t_{3}$ and sst $_{4}$ (27). ${ }^{111}$ In-DOTA-lanreotide, ${ }^{99 \mathrm{~m}}$ Tc-HYNIC-TOC and ${ }^{99 \mathrm{~m}}$ Tc-HYNIC-TATE have more or less similar sst-binding affinities as ${ }^{111}$ In-pentetreotide and the comparison of imaging with these compounds have shown similar results $(28,29,30)$.

\section{PET: PET/CT using ${ }^{68}$ Ga-DOTA-labelled SSAs}

In the recent decade, PET/CT using ${ }^{68} \mathrm{Ga}$-DOTA-labelled SSAs has been introduced for the diagnostic work-up of GEP-NETs. Three different ${ }^{68}$ Ga-DOTA-labelled SSAs are used in clinical practice: DOTANOC, DOTATATE and DOTATOC $(13,31,32,33,34)$. These compounds differ with regard to their individual affinity for the different ssts. ${ }^{68}$ Ga-DOTATATE has a high affinity for sst $_{2(a)}$, ${ }^{68} \mathrm{Ga}$-DOTATOC has a high affinity for $\mathrm{sst}_{2(\mathrm{a})}$ and $\mathrm{sst}_{5}$ and ${ }^{68} \mathrm{Ga}$-DOTANOC is $\mathrm{sst}_{2(\mathrm{a})}$, sst $_{3}$ and $\mathrm{sst}_{5}$ specific $(13,31,32$, 33 , 34). Somatostatin receptor PET/CT using ${ }^{68} \mathrm{Ga}$-DOTANOC, ${ }^{68} \mathrm{Ga}$-DOTATATE or ${ }^{68} \mathrm{Ga}$-DOTATOC is superior to SRS SPECT-CT showing higher sensitivities for GEP-NET lesion detection (more than 90\%), particularly due to a better special resolution or better sst affinities $(13,31,32$, 33, 34). These compounds are also more 'patient friendly', as they allow for imaging $1-3 \mathrm{~h}$ within i.v. injection $(13,31,32$, 33, 34). New ${ }^{68} \mathrm{Ga}$-DOTA-labelled SSAs for PET imaging include ${ }^{68} \mathrm{Ga}$-DOTAVAP and ${ }^{68} \mathrm{Ga}$-DOTALAN (27). In the near future, it can be expected that somatostatin receptor PET(-CT) will increasingly replace SRS SPECT(-CT). Currently, these techniques are not available in every centre.

\section{Metaiodobenzylguanidine scintigraphy}

Metaiodobenzylguanidine (MIBG - iobenguane) is taken up and stored by the catecholamine-secreting cells of the sympathetic and parasympathetic systems. Radioiodinated MIBG, ${ }^{123}$ I-MIBG ( or ${ }^{131}$ I-MIBG) is a guanethidine analogue that shares structural features with norepinephrine. At low concentrations, ${ }^{123}$ I-MIBG (or ${ }^{131}$ I-MIBG) is transported over the plasma membrane by the norepinephrine transporter or it enters the cell by passive diffusion. Within the cells, the vesicular monoamine transporters accumulate ${ }^{123}$ I-MIBG in catecholamine-storing granules (35). ${ }^{123}$ I-MIBG scintigraphy is generally used for imaging of functional pheochromocytomas, paragangliomas and neuroblastomas (36). However, ${ }^{123}$ I-MIBG (or ${ }^{131}$ I-MIBG) scintigraphy has a lower sensitivity than SRS for the imaging of NETs of the gastrointestinal tract (sensitivity $\sim 50 \%$ ) and pancreas (sensitivity $<10 \%$ ). However, in those patients with metastatic, inoperable, GEP-NETs and high uptake on MIBG scintigraphy, palliative treatment with ${ }^{131}$ I-MIBG might be considered $(37,38,39,40)$.

False-positive ${ }^{123}$ I-MIBG scintigraphy has been demonstrated in adrenocortical adenoma, adrenocortical carcinoma, angiomyolipoma and gastrointestinal stromal tumours (36).

\section{FDG PET: PET/CT}

${ }^{18}$ F-FDG PET provides images based on variations in glucose metabolism between normal, non-pathologic, and malignant cells and tissues. Patients in whom ${ }^{18}$ F-FDG PET has to be performed should fast for at least $6 \mathrm{~h}$ and blood glucose levels should be routinely assessed. Images are acquired 60-90 min after i.v. injection of ${ }^{18}$ F-FDG (13). Variable ${ }^{18}$ F-FDG uptake might be caused by muscle contractions, fasting, 'brown fat' activation and infections (41).

High ${ }^{18} \mathrm{~F}$-FDG uptake is usually associated with more aggressive GEP-NETs and a less favourable prognosis. The value of this imaging modality in most grades 1 and 2 GEP-NETs is limited, because of their limited growth velocity and, therefore, low glucose utilisation $(13,25,42)$. However, in grade 3 NECs, it might have additional value, especially in those cases where SRS is negative $(13,25$, $43,44) .{ }^{18}$ F-FDG PET might also have a role in the prediction of the GEP-NET and lung-NET responses to PRRT with ${ }^{177} \mathrm{Lu}$-octreotate. No tumour progression was found at follow-up in GEP-NET and lung-NET patients with a negative ${ }^{18}$ F-FDG PET finding treated with PRRT. However, patients with both a grade 2 NET and a positive ${ }^{18}$ F-FDG PET finding showed a less favourable disease course after PRRT, which in clinical practice might lead to changes in the therapeutic approach in this particular subgroup of GEP-NET patients (45).

\section{DOPA PET: PET/CT}

The efficacy of fluorine-18-L-3,4-dihydroxyphenylalanine $\left({ }^{18} \mathrm{~F}\right.$-DOPA) PET/CT is based on co-secretion of dopamine and hormones or peptides by GEP-NET cells. In these cells, L-DOPA is converted by the enzyme L-DOPA decarboxylase 
(a)

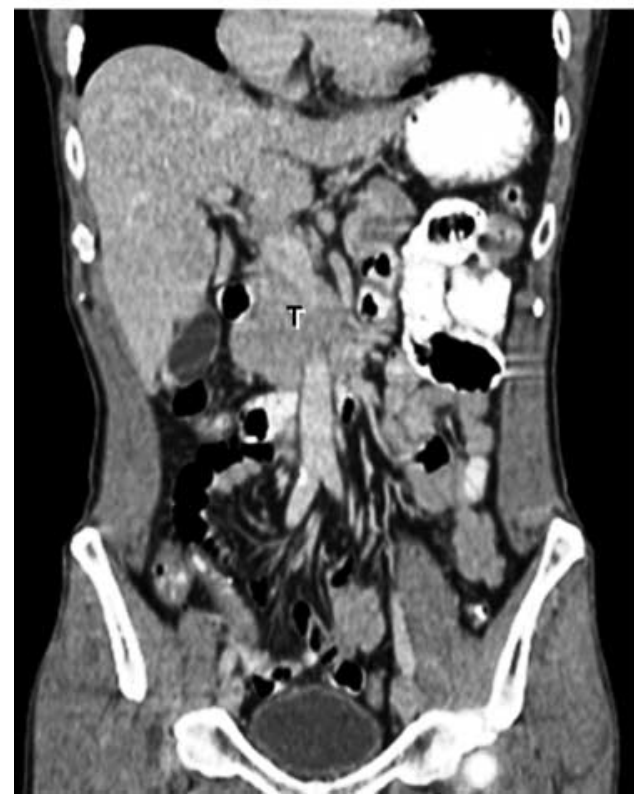

(b)

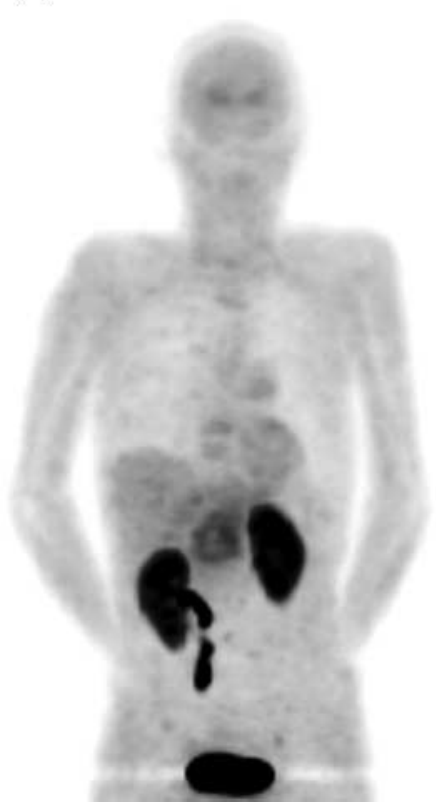

(c)

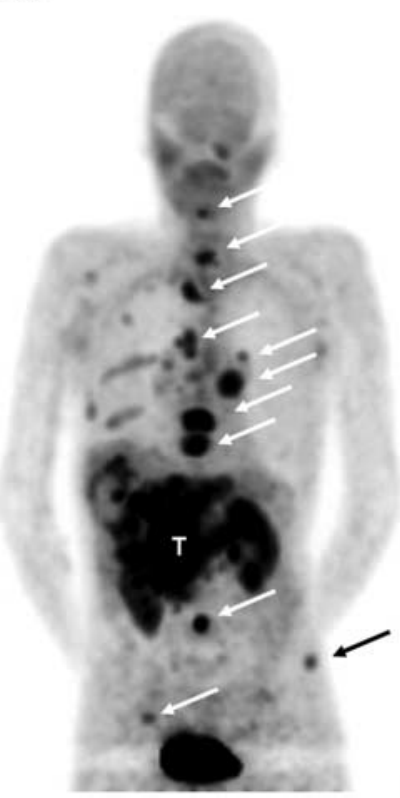

\section{Figure 2}

Functional images of a 54-year-old patient with a metastatic, clinically non-functioning, grade 2 , pancreatic neuroendocrine tumour: (a) coronal CT image showing a large pancreatic lesion (T), (b) coronal fluorine-18-L-3,4-dihydroxyphenylalanine

to dopamine. In comparative studies, ${ }^{18} \mathrm{~F}$-DOPA PET showed the highest sensitivity (98\%) as compared with SRS and ${ }^{11} \mathrm{C}-5$-hydroxy-L-tryptophan $\left({ }^{11} \mathrm{C}-5\right.$-HTP $)$ PET for the detection of NETs of the gastrointestinal tract, but not of the pancreas $(13,46) .{ }^{18} \mathrm{~F}$-DOPA PET tumour uptake reflects metabolic activity in NETs of the gastrointestinal tract (47). ${ }^{18} \mathrm{~F}$-DOPA PET/CT also has an important role in the diagnosis of congenital hyperinsulinism (OMIM \#601820), especially for the identification of focal forms (41, 48, 49, 50, 51, 52) (Fig. 2).

\section{5-HTP PET}

${ }^{11} \mathrm{C}-5$-HTP is a radiolabelled precursor in the serotonin synthesis. The short half-life of the ${ }^{11} \mathrm{C}$ radiolabel and complex synthesis considerably limits the worldwide availability and clinical use of ${ }^{11} \mathrm{C}-5$-HTP PET. In comparative studies, ${ }^{11} \mathrm{C}-5$-HTP PET showed the highest sensitivity (96\%) for the detection of pancreatic NETs as compared with CT, SRS and ${ }^{18}$ F-DOPA PET $(13,41,46,53$, 54). ${ }^{11} \mathrm{C}-5$-HTP PET was shown to be particularly useful for detecting small pancreatic NETs and early recurrences of pancreatic NETs (Fig. 3). $\left({ }^{18} \mathrm{~F}\right.$-DOPA) PET image showing absence of uptake and (c) coronal ${ }^{11} \mathrm{C}$-5-hydroxy-L-tryptophan $\left({ }^{11} \mathrm{C}-5\right.$-HTP) PET image showing uptake in the pancreatic lesion $(T)$ and in multiple metastatic bone and lymph node lesions (arrows). Courtesy of Prof. P L Jager.

\section{Gastrin receptor scintigraphy}

Cholecystokinin 2 (CCK2) receptor expression has been demonstrated in a high percentage of medullary thyroid carcinomas (MTCs). Several CCK2 receptor-binding radiopeptides have been developed for scintigraphy: ${ }^{111}$ In-DOTA-CCK, ${ }^{99 \mathrm{~m}}$ Tc-demogastrin and ${ }^{111}$ In-DOTAMG11 $(55,56,57)$. Particularly, ${ }^{99 \mathrm{~m}} \mathrm{Tc}$-demogastrin scintigraphy appeared to be most promising as a diagnostic tool in patients with (metastatic) MTC (55). ${ }^{68} \mathrm{Ga}$-DOTAminigastrin was developed for PET imaging of CCK2 receptor-positive tumours. ${ }^{68} \mathrm{Ga}$-DOTA-minigastrin PET/CT showed an almost 97\% sensitivity for the detection of tumour deposits in patients with MTC (56). In comparison, the detection rate of MTC with SRS is only $65 \%$ (58). As GEP-NETs also express CCK2 receptors, this imaging modality was also tested in a variety of GEP-NETs showing an overall tumour detection of almost $74 \%$ for ${ }^{68}$ Ga-DOTA-minigastrin PET (59).

\section{Glucagon-like peptide 1 receptor imaging}

The glucagon-like peptide 1 receptor (GLP1R) is mainly expressed on the pancreatic $\beta$-cells and is therefore an 


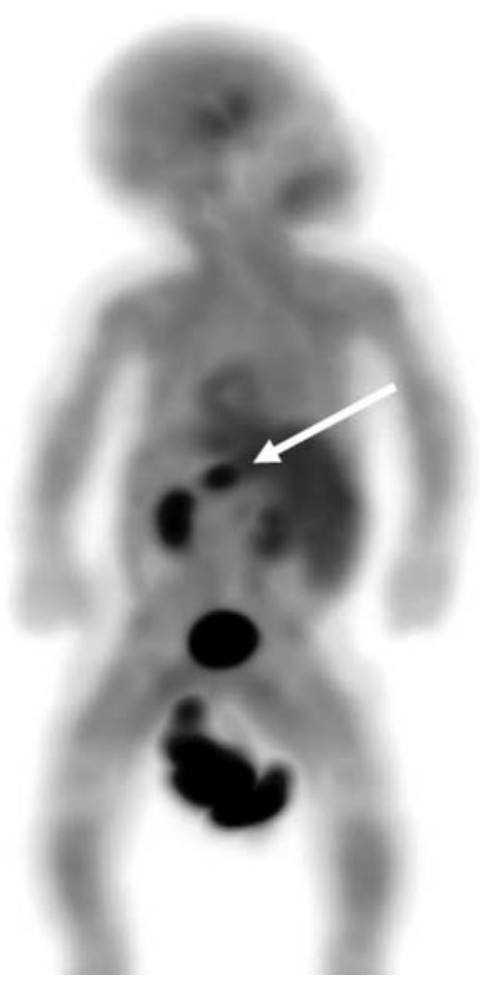

Figure 3

Coronal fluorine-18-L-3,4-dihydroxyphenylalanine ( $\left.{ }^{18} \mathrm{~F}-\mathrm{DOPA}\right)$ PET image of a 1-month-old baby boy with postpartum hypoglycaemia caused by the focal form of congenital hyperinsulinism (CHI, OMIM \#601820) showing pathologic uptake in part of the pancreas (arrow). Courtesy of Prof. P L Jager.

interesting target for imaging of (previously occult) insulinomas. However, as opposed to benign insulinomas, malignant insulinomas often lack GLP1R (60). Conversely, malignant insulinomas often do express $\mathrm{sst}_{2}$, which can be targeted using SRS $(24,60,61,62,63,64,65,66)$. In various studies, GLP1R scintigraphy using ${ }^{111}$ In-DOTAexendin-4 successfully detected benign insulinomas $(60$, $67,68,69,70)$. This radiopharmaceutical can also be successfully applied for the intraoperative localisation of these benign tumours (68).

Another radiopeptide used for targeting the GLP1R is (Lys(40)(Ahx-HYNIC- $\left.{ }^{99 \mathrm{~m}} \mathrm{Tc} / \mathrm{EDDA}\right) \mathrm{NH}_{2}$ )-exendin-4. GLP1R imaging using this compound has been studied in MTCs (71) and benign insulinomas (72). ${ }^{68} \mathrm{Ga}$-DOTAexendin-3 is a promising tracer to visualise insulinomas with PET (73).

\section{Vasoactive intestinal peptide receptor scintigraphy}

${ }^{123}$ I-labelled vasoactive intestinal peptide (VIP) receptor scintigraphy generally has lower sensitivity than SRS for GEP-NET localisation and is, therefore, generally not recommended for the diagnostic work-up of GEPNETs $(74,75,76)$.

\section{Sampling}

\section{Insulinoma}

Preoperative localisation of a benign (non-metastatic) sporadic insulinoma within the pancreas can be challenging. Several non-invasive localisation techniques are available, including: US, CT, MRI, SRS, ${ }^{68}$ Ga-DOTAlabelled SSA PET/CT, MIBG scintigraphy, 5-HTP PET, DOPA PET, GLP1R imaging as well as semi-invasive and invasive procedures, such as EUS, intraoperative US, pancreatic angiography, transhepatic portal venous sampling and selective intra-arterial calcium stimulation of insulin release by injection into the major pancreatic arteries with hepatic venous sampling (ASVS) for insulin gradients. ASVS for insulin gradients has been reported to be the most sensitive preoperative localising technique for

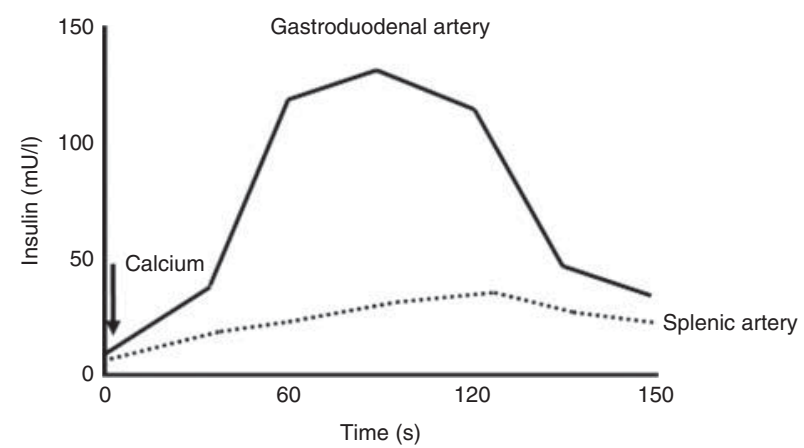

\section{Figure 4}

Insulin release stimulation in a 26-year-old woman with hypoglycaemia and hypserinsulinism. CT, MRI and endoscopic ultrasound (EUS) of the pancreas did not reveal any abnormalities. Transhepatic portal venous sampling and selective intraarterial calcium stimulation of insulin release by injection into the major pancreatic arteries with hepatic venous sampling (ASVS) for insulin gradients were performed and an insulin peak in the gastroduodenal artery was observed. During surgery, a $4 \mathrm{~mm}$ grade 1 neuroendocrine tumour (NET) in the pancreatic head could be removed. The tumour stained positive for insulin. After surgery, the hypoglycaemic episodes did not recur. 
insulinomas with reported successful localisation rates of $65-100 \%(77,78,79,80,81)$ (Fig. 4).

Administration of a hyperosmolar concentration of calcium gluconate into the vessels supplying the tumour will cause a release of insulin (and any other hormone secreted by that NET) into the portal venous system, resulting in a several-fold increase in insulin in blood samples obtained from the hepatic veins. The common hepatic artery (CHA), gastroduodenal artery (GDA), superior mesenteric artery (SMA) and splenic artery are injected and an appropriate rise in the level of insulin in samples obtained from the hepatic vein after the administration of
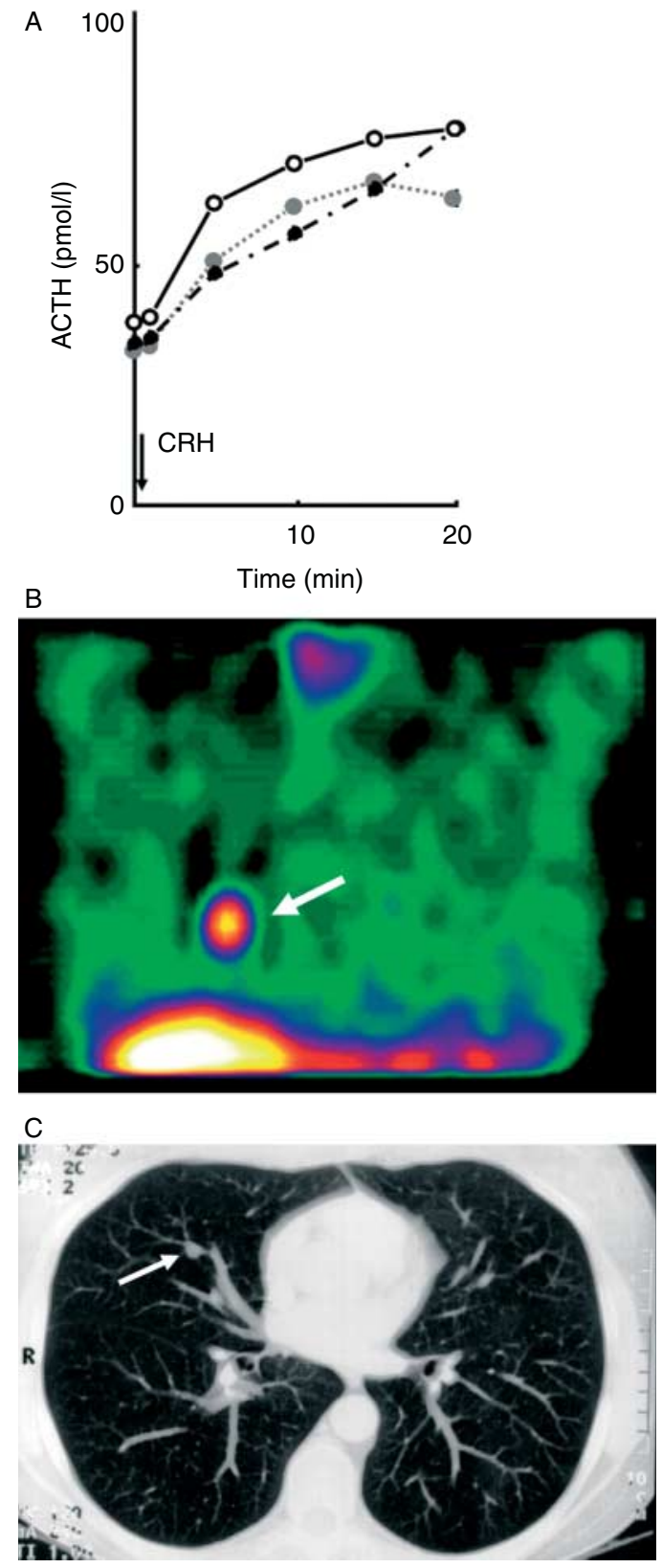

hyperosmolar calcium gluconate into the CHA, GDA or SMA will localise a lesion in the head of the pancreas, while a positive response following splenic artery injection predicts a lesion in the body or tail of the pancreas $(77,78,79,80,81)$.

\section{Sampling}

\section{Gastrinoma}

Ninety per cent of gastrinomas occur within the 'gastrinoma triangle'. This is the area bounded by the junction of the neck and body of the pancreas medially, the junction of the second and third parts of the duodenum inferiorly and the junction of the cystic and common bile ducts superiorly. SRS is the initial localisation study of choice, as this investigation, together with CT and EUS, will detect more than $90 \%$ of gastrinomas $(82,83,84,85)$. Therefore, the role of angiography and ASVS using secretin or calcium gluconate for localising gastrinomas is less clear-cut than in insulinomas. ASVS will provide both anatomical and functional information about the site of the gastrinoma and can be particularly useful for the difficult localisation of a sporadic duodenal gastrinoma $(86,87,88)$.

\section{Sampling}

\section{Ectopic adrenocorticotrophin secretion}

Bilateral sampling of the petrosal or cavernous sinuses for adrenocorticotrophin (ACTH) measurements before and

\section{Figure 5}

Adrenocorticotrophin (ACTH) response to corticotrophinreleasing hormone (CRH) stimulation in a 40-year-old woman with ACTH-dependent Cushing's syndrome and negative pituitary MRI findings in whom diagnosis of a typical ACTH-secreting lung carcinoid in the right lower lobe was made and a curative resection was performed. (A) Bilateral inferior petrosal sampling for $\mathrm{ACTH}$ before and after stimulation with $\mathrm{CRH}$. The figure shows no gradients between ACTH measurements in both inferior petrosal sinuses and a peripheral vein. This is illustrative for ectopic ACTH secretion. A positive ACTH response to $\mathrm{CRH}$ stimulation was observed, indicative of the presence of CRH receptors on the bronchial carcinoid. Open circle, right inferior petrosal sinus; grey shaded circle, peripheral vein; and black shaded circle, left inferior petrosal sinus. (B) Coronal OctreoScan image showing the pathologic uptake in the lower lobe of the right lung (arrow). (C) Transverse CT image showing the pathologic lesion (arrow), previously considered as a blood vessel. 
after the administration of corticotrophin-releasing hormone (CRH) has become an established and widely used diagnostic procedure in patients with ACTH-dependent Cushing's syndrome, especially in those cases with a negative or equivocal pituitary MRI finding $(89,90,91$, 92, 93) (Fig. 5). As the petrosal or cavernous sinuses are in close proximity to the anterior pituitary, basal and CRHstimulated ACTH levels in the blood from the inferior petrosal or cavernous sinus are generally higher than in the peripheral blood in the case of a pituitary source of ACTH overproduction. The lack of an appropriate ACTH gradient between the blood samples from the petrosal or cavernous sinuses and the peripheral blood vessels is indicative of an ectopic (non-pituitary) ACTH-secreting tumour (generally a NET). However, attempts to localise such an ectopic tumour by means of sampling several peripheral blood vessels for ACTH have generally turned out to be disappointing. Only a few case reports exist in which ACTH-secreting bronchial NETs could be localised using pulmonary arterial sampling (94, 95). However, generally CT, MRI and the different scintigraphy and PET techniques, as mentioned above, are more successful in the localisation of (occult) ACTH-producing extra-pituitary tumours $(89,90,91,92,93)$.

\section{Recommendation flow charts with regard to GEP-NET-specific imaging}

- Patients with well-differentiated (grades 1 and 2) NETs of the digestive tract: US, CT/MRI, SRS and DOPA PET.

- Patients with well-differentiated (grades 1 and 2) clinically non-functioning NETs of the pancreas: US, CT, EUS, MRI, SRS and HTP PET.

- Patients with insulinoma: US, CT, EUS, MRI, HTP PET, GLP1R imaging, SRS and ASVS.

- Patients with duodenal or pancreatic gastrinoma: SRS, US, CT, EUS, MRI, HTP PET and ASVS.

- Patients with other functioning pancreatic tumours: US, CT, EUS, MRI, SRS and HTP PET.

- Patients with poorly differentiated (grade 3) GEP-NECs: $\mathrm{CT}$ and FDG PET.

\section{Future directions}

Molecular imaging will continue to play an important role in the diagnosis and follow-up of GEP-NETs. It is apparent that PET techniques will gradually replace SPECT. New somatostatin receptor radioligands are being developed for clinical imaging. Not only somatostatin receptor agonists but also receptor antagonists are being studied (96). Other peptide receptors might also be interesting targets for receptor imaging, such as the gastrin-releasing peptide or bombesin receptors $(97,98,99)$.

Declaration of interest

The author declares that there is no conflict of interest that could be perceived as prejudicing the impartiality of the review.

\section{Funding}

This review did not receive any specific grant from any funding agency in the public, commercial or not-for-profit sector.

\section{References}

1 Modlin IM, Oberg K, Chung DC, Jensen RT, de Herder WW, Thakker RV, Caplin M, Delle Fave G, Kaltsas GA, Krenning EP et al. Gastroenteropancreatic neuroendocrine tumours Lancet. Oncology 20089 61-72. (doi:10.1016/S1470-2045(07)70410-2)

2 Kwekkeboom DJ, Kam BL, van Essen M, Teunissen JJ, van Eijck CH, Valkema R, de Jong M, de Herder WW \& Krenning EP. Somatostatinreceptor-based imaging and therapy of gastroenteropancreatic neuroendocrine tumors. Endocrine-Related Cancer 201017 R53-R73. (doi:10.1677/ERC-09-0078)

3 Kaltsas GA, Besser GM \& Grossman AB. The diagnosis and medical management of advanced neuroendocrine tumors. Endocrine Reviews 200425 458-511. (doi:10.1210/er.2003-0014)

4 Rindi G, Kloppel G, Alhman H, Caplin M, Couvelard A, de Herder WW Erikssson B, Falchetti A, Falconi M, Komminoth P et al. TNM staging of foregut (neuro)endocrine tumors: a consensus proposal including a grading system. Virchows Archiv 2006449 395-401. (doi:10.1007/ s00428-006-0250-1)

5 Rindi G, Kloppel G, Couvelard A, Komminoth P, Korner M, Lopes JM, McNicol AM, Nilsson O, Perren A, Scarpa A et al. TNM staging of midgut and hindgut (neuro) endocrine tumors: a consensus proposal including a grading system. Virchows Archiv 2007451 757-762. (doi:10.1007/ s00428-007-0452-1)

6 Pape UF, Jann H, Muller-Nordhorn J, Bockelbrink A, Berndt U, Willich SN, Koch M, Rocken C, Rindi G \& Wiedenmann B. Prognostic relevance of a novel TNM classification system for upper gastroenteropancreatic neuroendocrine tumors. Cancer 2008113 256-265. (doi:10.1002/cncr.23549)

7 Velayoudom-Cephise FL, Duvillard P, Foucan L, Hadoux J, Chougnet CN, Leboulleux S, Malka D, Guigay J, Goere D, Debaere T et al. Are G3 ENETS neuroendocrine neoplasms heterogeneous? Endocrine-Related Cancer 201320 649-657. (doi:10.1530/ERC-13-0027)

8 Araujo PB, Cheng S, Mete O, Serra S, Morin E, Asa SL \& Ezzat S. Evaluation of the WHO 2010 grading and AJCC/UICC staging systems in prognostic behavior of intestinal neuroendocrine tumors. PLOS ONE 20138 e61538. (doi:10.1371/journal.pone.0061538)

9 Khan MS, Luong TV, Watkins J, Toumpanakis C, Caplin ME \& Meyer T. A comparison of Ki-67 and mitotic count as prognostic markers for metastatic pancreatic and midgut neuroendocrine neoplasms. British Journal of Cancer 2013108 1838-1845. (doi:10.1038/bjc.2013.156)

10 Rindi G, Falconi M, Klersy C, Albarello L, Boninsegna L, Buchler MW, Capella C, Caplin M, Couvelard A, Doglioni C et al. TNM staging of neoplasms of the endocrine pancreas: results from a large international 
cohort study. Journal of the National Cancer Institute 2012104 764-777. (doi:10.1093/jnci/djs208)

11 Strosberg JR, Cheema A, Weber JM, Ghayouri M, Han G, Hodul PJ \& Kvols LK. Relapse-free survival in patients with nonmetastatic, surgically resected pancreatic neuroendocrine tumors: an analysis of the AJCC and ENETS staging classifications. Annals of Surgery 2012 256 321-325. (doi:10.1097/SLA.0b013e31824e6108)

12 Sundin A, Vullierme MP, Kaltsas G \& Plockinger U. ENETS consensus guidelines for the standards of care in neuroendocrine tumors: radiological examinations. Neuroendocrinology 200990 167-183. (doi:10.1159/000184855)

13 Sundin A. Radiological and nuclear medicine imaging of gastroenteropancreatic neuroendocrine tumours. Best Practice \& Research. Clinical Obstetrics \& Gynaecology 201226 803-818. (doi:10.1016/j.bpg.2012.12.004)

14 de Herder WW, Hofland LJ, van der Lely AJ \& Lamberts SW. Somatostatin receptors in gastroentero-pancreatic neuroendocrine tumours. Endocrine-Related Cancer 200310 451-458. (doi:10.1677/erc. $0.0100451)$

15 Veenstra MJ, de Herder WW, Feelders RA \& Hofland LJ. Targeting the somatostatin receptor in pituitary and neuroendocrine tumors. Expert Opinion on Therapeutic Targets 201317 1329-1343. (doi:10.1517/ 14728222.2013.830711)

16 de Herder WW \& Lamberts SW. Somatostatin analog therapy in treatment of gastrointestinal disorders and tumors. Endocrine 2003 20 285-290. (doi:10.1385/ENDO:20:3:285)

17 de Herder WW, Kwekkeboom DJ, Feelders RA, van Aken MO, Lamberts SW, van der Lely AJ \& Krenning EP. Somatostatin receptor imaging for neuroendocrine tumors. Pituitary 20069 243-248. (doi:10.1007/s11102-006-0270-5)

18 Balon HR, Goldsmith SJ, Siegel BA, Silberstein EB, Krenning EP, Lang O $\&$ Donohoe KJ. Procedure guideline for somatostatin receptor scintigraphy with (111)In-pentetreotide. Journal of Nuclear Medicine 200142 1134-1138.

19 Kwekkeboom DJ, Krenning EP, Scheidhauer K, Lewington V, Lebtahi R, Grossman A, Vitek P, Sundin A \& Plockinger U. ENETS consensus guidelines for the standards of care in neuroendocrine tumors: somatostatin receptor imaging with (111)In-pentetreotide. Neuroendocrinology 200990 184-189. (doi:10.1159/000225946)

20 Oberg K, Kvols L, Caplin M, Delle Fave G, de Herder W, Rindi G, Ruszniewski P, Woltering EA \& Wiedenmann B. Consensus report on the use of somatostatin analogs for the management of neuroendocrine tumors of the gastroenteropancreatic system. Annals of Oncology 2004 15 966-973. (doi:10.1093/annonc/mdh216)

21 Lamberts SW, van der Lely AJ, de Herder WW \& Hofland LJ. Octreotide. New England Journal of Medicine 1996334 246-254. (doi:10.1056/ NEJM199601253340408)

22 Zaknun JJ, Bodei L, Mueller-Brand J, Pavel ME, Baum RP, Horsch D, O'Dorisio MS, O'Dorisiol TM, Howe JR, Cremonesi M et al. The joint IAEA, EANM, and SNMMI practical guidance on peptide receptor radionuclide therapy (PRRNT) in neuroendocrine tumours. European Journal of Nuclear Medicine and Molecular Imaging 201340 800-816. (doi:10.1007/s00259-012-2330-6)

23 Kwekkeboom DJ, Krenning EP, Lebtahi R, Komminoth P, Kos-Kudla B, de Herder WW \& Plockinger U. ENETS consensus guidelines for the standards of care in neuroendocrine tumors: peptide receptor radionuclide therapy with radiolabeled somatostatin analogs. Neuroendocrinology 200990 220-226. (doi:10.1159/000225951)

24 de Herder WW, Niederle B, Scoazec JY, Pauwels S, Kloppel G, Falconi M, Kwekkeboom DJ, Oberg K, Eriksson B, Wiedenmann B et al. Well-differentiated pancreatic tumor/carcinoma: insulinoma. Neuroendocrinology 200684 183-188. (doi:10.1159/000098010)

25 Binderup T, Knigge U, Loft A, Mortensen J, Pfeifer A, Federspiel B, Hansen CP, Hojgaard L \& Kjaer A. Functional imaging of neuroendocrine tumors: a head-to-head comparison of somatostatin receptor scintigraphy, ${ }^{123}$ I-MIBG scintigraphy, and ${ }^{18} \mathrm{~F}$-FDG PET. Journal of Nuclear Medicine 201051 704-712. (doi:10.2967/jnumed.109.069765)
26 Shah T, Kulakiene I, Quigley AM, Warbey VS, Srirajaskanthan R, Toumpanakis C, Hochhauser D, Buscombe J \& Caplin ME. The role of 99mTc-depreotide in the management of neuroendocrine tumours. Nuclear Medicine Communications 200829 436-440. (doi:10.1097/ MNM.0b013e3282f50747)

27 Heppeler A, Froidevaux S, Eberle AN \& Maecke HR. Receptor targeting for tumor localisation and therapy with radiopeptides. Current Medicinal Chemistry 20007 971-994. (doi:10.2174/0929867003374516)

28 Smith-Jones PM, Bischof C, Leimer M, Gludovacz D, Angelberger P, Pangerl T, Peck-Radosavljevic M, Hamilton G, Kaserer K, Kofler A et al. DOTA-lanreotide: a novel somatostatin analog for tumor diagnosis and therapy. Endocrinology 1999140 5136-5148.

29 Cwikla JB, Mikolajczak R, Pawlak D, Buscombe JR, NasierowskaGuttmejer A, Bator A, Maecke HR \& Walecki J. Initial direct comparison of $99 \mathrm{mTc}$-TOC and $99 \mathrm{mTc}$-TATE in identifying sites of disease in patients with proven GEP NETs. Journal of Nuclear Medicine $2008 \mathbf{4 9}$ 1060-1065. (doi:10.2967/jnumed.107.046961)

30 Gabriel M, Muehllechner P, Decristoforo C, von Guggenberg E, Kendler D, Prommegger R, Profanter C, Moncayo R \& Virgolini I. 99mTc-EDDA/HYNIC-Tyr(3)-octreotide for staging and follow-up of patients with neuroendocrine gastro-entero-pancreatic tumors. Quarterly Journal of Nuclear Medicine and Molecular Imaging 200549 237-244.

31 Wild D, Bomanji JB, Benkert P, Maecke H, Ell PJ, Reubi JC \& Caplin ME. Comparison of ${ }^{68} \mathrm{Ga}$-DOTANOC and ${ }^{68} \mathrm{Ga}$-DOTATATE PET/CT within patients with gastroenteropancreatic neuroendocrine tumors. Journal of Nuclear Medicine 201354 364-372. (doi:10.2967/jnumed.112.111724)

32 Haug AR, Cindea-Drimus R, Auernhammer CJ, Reincke M, Wangler B, Uebleis C, Schmidt GP, Goke B, Bartenstein P \& Hacker M. The role of ${ }^{68} \mathrm{Ga}$-DOTATATE PET/CT in suspected neuroendocrine tumors. Journal of Nuclear Medicine 201253 1686-1692. (doi:10.2967/jnumed. 111.101675)

33 Schraml C, Schwenzer NF, Sperling O, Aschoff P, Lichy MP, Muller M, Brendle C, Werner MK, Claussen CD \& Pfannenberg C. Staging of neuroendocrine tumours: comparison of $\left({ }^{68} \mathrm{Ga}\right)$ DOTATOC multiphase PET/CT and whole-body MRI. Cancer Imaging 201313 63-72. (doi:10.1102/1470-7330.2013.0007)

34 Ambrosini V, Campana D, Nanni C, Cambioli S, Tomassetti P, Rubello D \& Fanti S. Is ${ }^{68} \mathrm{Ga}$-DOTA-NOC PET/CT indicated in patients with clinical, biochemical or radiological suspicion of neuroendocrine tumour? European Journal of Nuclear Medicine and Molecular Imaging 2012 39 1278-1283. (doi:10.1007/s00259-012-2146-4)

35 Bombardieri E, Aktolun C, Baum RP, Bishof-Delaloye A, Buscombe J, Chatal JF, Maffioli L, Moncayo R, Mortelmans L \& Reske SN. ${ }^{131} \mathrm{I} /{ }^{123}$ I-metaiodobenzylguanidine (MIBG), scintigraphy: procedure guidelines for tumour imaging. European Journal of Nuclear Medicine and Molecular Imaging 200330 BP132-BP139.

36 Jacobson AF, Deng H, Lombard J, Lessig HJ \& Black RR. ${ }^{123}$ I-metaiodobenzylguanidine scintigraphy for the detection of neuroblastoma and pheochromocytoma: results of a meta-analysis. Journal of Clinical Endocrinology and Metabolism 201095 2596-2606. (doi:10.1210/ jc.2009-2604)

37 Kaltsas G, Korbonits M, Heintz E, Mukherjee JJ, Jenkins PJ, Chew SL, Reznek R, Monson JP, Besser GM, Foley R et al. Comparison of somatostatin analog and meta-iodobenzylguanidine radionuclides in the diagnosis and localization of advanced neuroendocrine tumors. Journal of Clinical Endocrinology and Metabolism 200186 895-902. (doi:10.1210/jcem.86.2.7194)

38 Kaltsas G, Rockall A, Papadogias D, Reznek R \& Grossman AB. Recent advances in radiological and radionuclide imaging and therapy of neuroendocrine tumours. European Journal of Endocrinology 2004151 15-27. (doi:10.1530/eje.0.1510015)

39 Buscombe JR, Cwikla JB, Caplin ME \& Hilson AJ. Long-term efficacy of low activity meta- $\left({ }^{131}\right.$ I)iodobenzylguanidine therapy in patients with disseminated neuroendocrine tumours depends on initial response. Nuclear Medicine Communications 200526 969-976. (doi:10.1097/ 01.mnm.0000184941.06123.b9) 
40 Taal BG, Zuetenhorst H, Valdes Olmos RA \& Hoefnagel CA. $\left({ }^{131} \mathrm{I}\right) \mathrm{MIBG}$ radionuclide therapy in carcinoid syndrome. European Journal of Surgical Oncology 200228 243. (doi:10.1053/ejso.2001.1225)

41 Rufini V, Baum RP, Castaldi P, Treglia G, De Gaetano AM, Carreras C, Kaemmerer D, Hommann M, Horsch D, Bonomo L et al. Role of PET/CT in the functional imaging of endocrine pancreatic tumors. Abdominal Imaging 201237 1004-1020. (doi:10.1007/s00261-012-9871-9)

42 Naswa N, Sharma P, Gupta SK, Karunanithi S, Reddy RM, Patnecha M, Lata S, Kumar R, Malhotra A \& Bal C. Dual tracer functional imaging of gastroenteropancreatic neuroendocrine tumors using ${ }^{68} \mathrm{Ga}$-DOTANOC PET-CT and ${ }^{18}$ F-FDG PET-CT: competitive or complimentary? Clinical Nuclear Medicine 201439 e27-e34. (doi:10.1097/RLU. 0b013e31827a216b)

43 Binderup T, Knigge U, Loft A, Federspiel B \& Kjaer A. ${ }^{18}$ F-fluorodeoxyglucose positron emission tomography predicts survival of patients with neuroendocrine tumors. Clinical Cancer Research 201016 978-985. (doi:10.1158/1078-0432.CCR-09-1759)

44 Abgral R, Leboulleux S, Deandreis D, Auperin A, Lumbroso J, Dromain C, Duvillard P, Elias D, de Baere T, Guigay J et al. Performance of (18) fluorodeoxyglucose-positron emission tomography and somatostatin receptor scintigraphy for high Ki67 ( $\geq 10 \%)$ welldifferentiated endocrine carcinoma staging. Journal of Clinical Endocrinology and Metabolism 201196 665-671. (doi:10.1210/jc.2010-2022)

45 Severi S, Nanni O, Bodei L, Sansovini M, Ianniello A, Nicoletti S, Scarpi E, Matteucci F, Gilardi L \& Paganelli G. Role of ${ }^{18}$ FDG PET/CT in patients treated with ${ }^{177} \mathrm{Lu}$-DOTATATE for advanced differentiated neuroendocrine tumours. European Journal of Nuclear Medicine and Molecular Imaging 201340 881-888. (doi:10.1007/s00259-013-2369-z)

46 van Essen M, Sundin A, Krenning EP \& Kwekkeboom DJ. Neuroendocrine tumours: the role of imaging for diagnosis and therapy. Nature Reviews. Endocrinology 201410 102-114. (doi:10.1038/nrendo.2013.246)

47 Fiebrich HB, de Jong JR, Kema IP, Koopmans KP, Sluiter W, Dierckx RA, Walenkamp AM, Links TP, Brouwers AH \& de Vries EG. Total ${ }^{18} \mathrm{~F}$-dopa PET tumour uptake reflects metabolic endocrine tumour activity in patients with a carcinoid tumour. European Journal of Nuclear Medicine and Molecular Imaging 201138 1854-1861. (doi:10.1007/s00259-011-1862-5)

48 Zani A, Nah SA, Ron O, Totonelli G, Ismail D, Smith VV, Ashworth M, Blankenstein O, Mohnike W, De Coppi P et al. The predictive value of preoperative fluorine-18-L-3,4-dihydroxyphenylalanine positron emission tomography-computed tomography scans in children with congenital hyperinsulinism of infancy. Journal of Pediatric Surgery 2011 46 204-208. (doi:10.1016/j.jpedsurg.2010.09.093)

49 Mohnike W, Barthlen W, Mohnike K \& Blankenstein O. Positron emission tomography/computed tomography diagnostics by means of fluorine18-L-dihydroxyphenylalanine in congenital hyperinsulinism. Seminars in Pediatric Surgery 201120 23-27. (doi:10.1053/j.sempedsurg.2010.10.007)

50 Ismail D, Smith VV, de Lonlay P, Ribeiro MJ, Rahier J, Blankenstein O, Flanagan SE, Bellanne-Chantelot C, Verkarre V, Aigrain Y et al. Familial focal congenital hyperinsulinism. Journal of Clinical Endocrinology and Metabolism 201196 24-28. (doi:10.1210/jc.2010-1524)

51 Ismail D, Kapoor RR, Smith VV, Ashworth M, Blankenstein O, Pierro A, Flanagan SE, Ellard S \& Hussain K. The heterogeneity of focal forms of congenital hyperinsulinism. Journal of Clinical Endocrinology and Metabolism 201297 E94-E99. (doi:10.1210/jc.2011-1628)

52 Barthlen W, Blankenstein O, Mau H, Koch M, Hohne C, Mohnike W, Eberhard T, Fuechtner F, Lorenz-Depiereux B \& Mohnike K. Evaluation of $\left({ }^{18} \mathrm{~F}\right)$ fluoro-L-DOPA positron emission tomography-computed tomography for surgery in focal congenital hyperinsulinism. Journal of Clinical Endocrinology and Metabolism 200893 869-875. (doi:10.1210/ jc.2007-2036)

53 Orlefors H, Sundin A, Ahlstrom H, Bjurling P, Bergstrom M, Lilja A, Langstrom B, Oberg K \& Eriksson B. Positron emission tomography with 5-hydroxytryptophan in neuroendocrine tumors. Journal of Clinical Oncology 199816 2534-2541.

54 Orlefors H, Sundin A, Garske U, Juhlin C, Oberg K, Langstrom B, Bergstrom M \& Eriksson B. Whole-body ${ }^{11} \mathrm{C}-5$-hydroxytryptophan positron emission tomography as a universal imaging technique for neuroendocrine tumors - comparison with somatostatin receptor scintigraphy and computed tomography. Journal of Clinical Endocrinology and Metabolism 200590 3392-3400. (doi:10.1210/jc.2004-1938)

55 Froberg AC, de Jong M, Nock BA, Breeman WA, Erion JL, Maina T, Verdijsseldonck M, de Herder WW, van der Lugt A, Kooij PP et al. Comparison of three radiolabelled peptide analogues for CCK-2 receptor scintigraphy in medullary thyroid carcinoma. European Journal of Nuclear Medicine and Molecular Imaging 200936 1265-1272. (doi:10.1007/s00259-009-1098-9)

56 Gotthardt M, Behe MP, Beuter D, Battmann A, Bauhofer A, Schurrat T, Schipper M, Pollum H, Oyen WJ \& Behr TM. Improved tumour detection by gastrin receptor scintigraphy in patients with metastasised medullary thyroid carcinoma. European Journal of Nuclear Medicine and Molecular Imaging 200633 1273-1279. (doi:10.1007/s00259-006-0157-8)

57 Nock BA, Maina T, Behe M, Nikolopoulou A, Gotthardt M, Schmitt JS, Behr TM \& Macke HR. CCK-2/gastrin receptor-targeted tumor imaging with $(99 \mathrm{~m})$ Tc-labeled minigastrin analogs. Journal of Nuclear Medicine 200546 1727-1736.

58 Kwekkeboom DJ, Reubi JC, Lamberts SW, Bruining HA, Mulder AH, Oei HY \& Krenning EP. In vivo somatostatin receptor imaging in medullary thyroid carcinoma. Journal of Clinical Endocrinology and Metabolism 199376 1413-1417.

59 Gotthardt M, Behe MP, Grass J, Bauhofer A, Rinke A, Schipper ML, Kalinowski M, Arnold R, Oyen WJ \& Behr TM. Added value of gastrin receptor scintigraphy in comparison to somatostatin receptor scintigraphy in patients with carcinoids and other neuroendocrine tumours. Endocrine-Related Cancer 200613 1203-1211. (doi:10.1677/erc.1.01245)

60 Wild D, Christ E, Caplin ME, Kurzawinski TR, Forrer F, Brandle M, Seufert J, Weber WA, Bomanji J, Perren A et al. Glucagon-like peptide-1 versus somatostatin receptor targeting reveals 2 distinct forms of malignant insulinomas. Journal of Nuclear Medicine 201152 1073-1078. (doi:10.2967/jnumed.110.085142)

61 Vezzosi D, Bennet A, Courbon F \& Caron P. Short- and long-term somatostatin analogue treatment in patients with hypoglycaemia related to endogenous hyperinsulinism. Clinical Endocrinology 2008 68 904-911. (doi:10.1111/j.1365-2265.2007.03136.x)

62 Vezzosi D, Bennet A, Rochaix P, Courbon F, Selves J, Pradere B, Buscail L, Susini C \& Caron P. Octreotide in insulinoma patients: efficacy on hypoglycemia, relationships with Octreoscan scintigraphy and immunostaining with anti-sst2A and anti-sst5 antibodies. European Journal of Endocrinology 2005152 757-767. (doi:10.1530/eje.1.01901)

63 van Schaik E, van Vliet EI, Feelders RA, Krenning EP, Khan S, Kamp K, Valkema R, van Nederveen FH, Teunissen JJ, Kwekkeboom DJ et al. Improved control of severe hypoglycemia in patients with malignant insulinomas by peptide receptor radionuclide therapy. Journal of Clinical Endocrinology and Metabolism 201196 3381-3389. (doi:10.1210/ jc.2011-1563)

64 de Herder WW, van Schaik E, Kwekkeboom D \& Feelders RA. New therapeutic options for metastatic malignant insulinomas. Clinical Endocrinology 201175 277-284. (doi:10.1111/j.1365-2265.2011.04145.x)

65 Bertherat J, Tenenbaum F, Perlemoine K, Videau C, Alberini JL, Richard B, Dousset B, Bertagna X \& Epelbaum J. Somatostatin receptors 2 and 5 are the major somatostatin receptors in insulinomas: an in vivo and in vitro study. Journal of Clinical Endocrinology and Metabolism 2003 88 5353-5360. (doi:10.1210/jc.2002-021895)

66 Portela-Gomes GM, Stridsberg M, Grimelius L, Rorstad O \& Janson ET. Differential expression of the five somatostatin receptor subtypes in human benign and malignant insulinomas - predominance of receptor subtype 4. Endocrine Pathology 200718 79-85. (doi:10.1007/ s12022-007-0014-8)

67 Wild D, Macke H, Christ E, Gloor B \& Reubi JC. Glucagon-like peptide 1-receptor scans to localize occult insulinomas. New England Journal of Medicine 2008359 766-768. (doi:10.1056/NEJMc0802045)

68 Christ E, Wild D, Forrer F, Brandle M, Sahli R, Clerici T, Gloor B, Martius F, Maecke H \& Reubi JC. Glucagon-like peptide-1 receptor 
imaging for localization of insulinomas. Journal of Clinical Endocrinology and Metabolism 200994 4398-4405. (doi:10.1210/jc.2009-1082)

69 Christ E, Wild D, Ederer S, Behe M, Nicolas G, Caplin ME, Brandle M, Clerici T, Fischli S, Stettler C et al. Glucagon-like peptide-1 receptor imaging for the localisation of insulinomas: a prospective multicentre imaging study. Lancet. Diabetes \& Endocrinology 20131 115-122. (doi:10.1016/S2213-8587(13)70049-4)

70 Grossman A. The nuclear option for insulinomas. Lancet. Diabetes \& Endocrinology 20131 82-84. (doi:10.1016/S2213-8587(13)70060-3)

71 Pach D, Sowa-Staszczak A, Jabrocka-Hybel A, Stefanska A, Tomaszuk M, Mikolajczak R, Janota B, Trofimiuk-Muldner M, Przybylik-Mazurek E \& Hubalewska-Dydejczyk A. Glucagon-like peptide-1 receptor imaging with (Lys(40) (Ahx-HYNIC-(99m)Tc/EDDA)NH 2)-exendin-4 for the diagnosis of recurrence or dissemination of medullary thyroid cancer: a preliminary report. International Journal of Endocrinology 20132013 384508. (doi:10.1155/2013/384508)

72 Sowa-Staszczak A, Pach D, Mikolajczak R, Macke H, Jabrocka-Hybel A, Stefanska A, Tomaszuk M, Janota B, Gilis-Januszewska A, Malecki M et al. Glucagon-like peptide-1 receptor imaging with (Lys40(AhxHYNIC-99mTc/EDDA)NH2)-exendin-4 for the detection of insulinoma. European Journal of Nuclear Medicine and Molecular Imaging 2013 40 524-531. (doi:10.1007/s00259-012-2299-1)

73 Brom M, Oyen WJ, Joosten L, Gotthardt M \& Boerman OC. ${ }^{68} \mathrm{Ga}$-labelled exendin-3, a new agent for the detection of insulinomas with PET. European Journal of Nuclear Medicine and Molecular Imaging 201037 1345-1355. (doi:10.1007/s00259-009-1363-y)

74 Hessenius C, Bader M, Meinhold H, Bohmig M, Faiss S, Reubi JC \& Wiedenmann B. Vasoactive intestinal peptide receptor scintigraphy in patients with pancreatic adenocarcinomas or neuroendocrine tumours. European Journal of Nuclear Medicine 200027 1684-1693. (doi:10.1007/ s002590000325)

75 Virgolini I, Kurtaran A, Leimer M, Kaserer K, Peck-Radosavljevic M, Angelberger P, Hubsch P, Dvorak M, Valent P \& Niederle B. Location of a VIPoma by iodine-123-vasoactive intestinal peptide scintigraphy. Journal of Nuclear Medicine 199839 1575-1579.

76 Virgolini I, Raderer M, Kurtaran A, Angelberger P, Banyai S, Yang Q, Li S, Banyai M, Pidlich J, Niederle B et al. Vasoactive intestinal peptidereceptor imaging for the localization of intestinal adenocarcinomas and endocrine tumors. New England Journal of Medicine 1994331 1116-1121. (doi:10.1056/NEJM199410273311703)

77 Druce MR, Muthuppalaniappan VM, O'Leary B, Chew SL, Drake WM, Monson JP, Akker SA, Besser M, Sahdev A, Rockall A et al. Diagnosis and localisation of insulinoma: the value of modern magnetic resonance imaging in conjunction with calcium stimulation catheterisation. European Journal of Endocrinology 2010162 971-978. (doi:10.1530/ EJE-10-0056)

78 Doppman JL, Chang R, Fraker DL, Norton JA, Alexander HR, Miller DL, Collier E, Skarulis MC \& Gorden P. Localization of insulinomas to regions of the pancreas by intra-arterial stimulation with calcium. Annals of Internal Medicine 1995123 269-273. (doi:10.7326/0003-4819123-4-199508150-00004)

79 Doherty GM, Doppman JL, Shawker TH, Miller DL, Eastman RC, Gorden P \& Norton JA. Results of a prospective strategy to diagnose, localize, and resect insulinomas. Surgery 1991110 989-996.

80 Braatvedt G, Jennison E \& Holdaway IM. Comparison of two low-dose calcium infusion schedules for localization of insulinomas by selective pancreatic arterial injection with hepatic venous sampling for insulin. Clinical Endocrinology 201480 80-84. (doi:10.1111/cen.12253)

81 Lo CY, Chan FL, Tam SC, Cheng PW, Fan ST \& Lam KS. Value of intraarterial calcium stimulated venous sampling for regionalization of pancreatic insulinomas. Surgery 2000128 903-909. (doi:10.1067/ msy.2000.109729)

82 Gibril F, Reynolds JC, Doppman JL, Chen CC, Venzon DJ, Termanini B, Weber HC, Stewart CA \& Jensen RT. Somatostatin receptor scintigraphy: its sensitivity compared with that of other imaging methods in detecting primary and metastatic gastrinomas. A prospective study.
Annals of Internal Medicine 1996125 26-34. (doi:10.7326/0003-4819125-1-199607010-00005)

83 Jensen RT \& Gibril F. Somatostatin receptor scintigraphy in gastrinomas. Italian Journal of Gastroenterology and Hepatology 199931 (Suppl 2) S179-S185.

84 Jensen RT, Cadiot G, Brandi ML, de Herder WW, Kaltsas G, Komminoth P, Scoazec JY, Salazar R, Sauvanet A \& Kianmanesh R. ENETS consensus guidelines for the management of patients with digestive neuroendocrine neoplasms: functional pancreatic endocrine tumor syndromes. Neuroendocrinology 201295 98-119. (doi:10.1159/ 000335591)

85 Krenning EP, Kwekkeboom DJ, Oei HY, de Jong RJ, Dop FJ, de Herder WW, Reubi JC \& Lamberts SW. Somatostatin receptor scintigraphy in carcinoids, gastrinomas and Cushing's syndrome. Digestion 199455 (Suppl 3) 54-59. (doi:10.1159/000201202)

86 Jackson JE. Angiography and arterial stimulation venous sampling in the localization of pancreatic neuroendocrine tumours. Best Practice and Research. Clinical Endocrinology \& Metabolism 200519 229-239. (doi:10.1016/j.beem.2004.10.002)

87 Cherner JA, Doppman JL, Norton JA, Miller DL, Krudy AG, Raufman JP, Collen MJ, Maton PN, Gardner JD \& Jensen RT. Selective venous sampling for gastrin to localize gastrinomas. A prospective assessment. Annals of Internal Medicine 1986105 841-847. (doi:10.7326/0003-4819. 105-6-841)

88 Doppman JL, Miller DL, Chang R, Maton PN, London JF, Gardner JD, Jensen RT \& Norton JA. Gastrinomas: localization by means of selective intraarterial injection of secretin. Radiology 1990174 25-29.

89 Isidori AM, Kaltsas GA, Pozza C, Frajese V, Newell-Price J, Reznek RH, Jenkins PJ, Monson JP, Grossman AB \& Besser GM. The ectopic adrenocorticotropin syndrome: clinical features, diagnosis, management, and long-term follow-up. Journal of Clinical Endocrinology and Metabolism 200691 371-377. (doi:10.1210/jc.2005-1542)

90 de Herder WW, Uitterlinden P, Pieterman H, Tanghe HL, Kwekkeboom DJ, Pols HA, Singh R, van de Berge JH \& Lamberts SW. Pituitary tumour localization in patients with Cushing's disease by magnetic resonance imaging. Is there a place for petrosal sinus sampling? Clinical Endocrinology 199440 87-92. (doi:10.1111/j.13652265.1994.tb02448.x)

91 Lamberts SW, de Herder WW, Krenning EP \& Reubi JC. A role of (labeled) somatostatin analogs in the differential diagnosis and treatment of Cushing's syndrome. Journal of Clinical Endocrinology and Metabolism 199478 17-19.

92 de Herder WW, Krenning EP, Malchoff CD, Hofland LJ, Reubi JC, Kwekkeboom DJ, Oei HY, Pols HA, Bruining HA \& Nobels FR. Somatostatin receptor scintigraphy: its value in tumor localization in patients with Cushing's syndrome caused by ectopic corticotropin or corticotropin-releasing hormone secretion. American Journal of Medicine 199496 305-312. (doi:10.1016/0002-9343(94)90059-0)

93 Zemskova MS, Gundabolu B, Sinaii N, Chen CC, Carrasquillo JA, Whatley M, Chowdhury I, Gharib AM \& Nieman LK. Utility of various functional and anatomic imaging modalities for detection of ectopic adrenocorticotropin-secreting tumors. Journal of Clinical Endocrinology and Metabolism 201095 1207-1219. (doi:10.1210/ jc.2009-2282)

94 Sugiyama M, Sugiyama T, Yamaguchi M, Izumiyama H, Yoshimoto T, Kishino M, Akashi T \& Hirata Y. Successful localization of ectopic ACTH-secreting bronchial carcinoid by selective pulmonary arterial sampling. Endocrine Journal 201057 959-964. (doi:10.1507/ endocri.K10E-192)

95 Sakuma I, Saito J, Matsuzawa Y, Omura M, Matsui S, Maehara T, Hasegawa N \& Nishikawa T. Pulmonary arterial sampling was useful for localizing ectopic ACTH production in a patient with bronchial carcinoid causing Cushing syndrome. Hormones 2013 12 449-453.

96 Wang X, Fani M, Schulz S, Rivier J, Reubi JC \& Maecke HR. Comprehensive evaluation of a somatostatin-based radiolabelled 
antagonist for diagnostic imaging and radionuclide therapy. European Journal of Nuclear Medicine and Molecular Imaging 201239 1876-1885. (doi:10.1007/s00259-012-2231-8)

97 Marsouvanidis PJ, Maina T, Sallegger W, Krenning EP, de Jong M \& Nock BA. 99mTc radiotracers based on human GRP(18-27): synthesis and comparative evaluation. Journal of Nuclear Medicine $2013 \mathbf{5 4}$ 1797-1803. (doi:10.2967/jnumed.112.118695)

98 Richter S, Wuest M, Krieger SS, Rogers BE, Friebe M, Bergmann R \& Wuest F. Synthesis and radiopharmacological evaluation of a high-affinity and metabolically stabilized ${ }^{18}$ F-labeled bombesin analogue for molecular imaging of gastrin-releasing peptide receptor-expressing prostate cancer. Nuclear Medicine and Biology 2013 40 1025-1034. (doi:10.1016/j.nucmedbio.2013.07.005)

99 Varasteh Z, Aberg O, Velikyan I, Lindeberg G, Sorensen J, Larhed M, Antoni $\mathrm{G}$, Sandstrom $\mathrm{M}$, Tolmachev V \& Orlova A. In vitro and in vivo evaluation of a (18)F-labeled high affinity NOTA conjugated bombesin antagonist as a PET ligand for GRPR-targeted tumor imaging. PLOS ONE 20138 e81932. (doi:10.1371/journal.pone.0081932)

Received 26 January 2014

Revised version received 5 February 2014

Accepted 10 February 2014 